\title{
Flexible Working Practices: Urgency or Future?
}

\author{
Azamat Sulaymonov \\ International Business School, the Hague, Netherlands \\ Email: azamat_s89@mail.ru
}

How to cite this paper: Sulaymonov, A. (2020). Flexible Working Practices: Urgency or Future? Modern Economy, 11, 1342-1350. https://doi.org/10.4236/me.2020.117095

Received: March 25, 2020

Accepted: July 19, 2020

Published: July 22, 2020

Copyright (c) 2020 by author(s) and Scientific Research Publishing Inc. This work is licensed under the Creative Commons Attribution International License (CC BY 4.0).

http://creativecommons.org/licenses/by/4.0/

\begin{abstract}
With the prevalence of COVID-19, flexible working practices have gained wider appliance ever before. This paper has three objectives. First, it seeks to develop a theoretical framework that encompasses the roots of gaining popularity of FWAs, its essence and aims, and range of practical approaches to flexibility. Second, it sheds light on the outcomes of practical use of flexibility into workplaces. Third, it introduces challenges of FW on managers and supervisors.
\end{abstract}

\section{Keywords}

Flexible Working Practices, Part-Time Working, Job Sharing, Telecommuting/Mobile Workplace, Compressed Work Week

\section{Introduction}

Today, one does not need to be an astute futurologist to understand: the world is in the process of explosive technological transformation. In the history of mankind, technological revolutions have always accumulated for a long time and gradually, but sooner or later a trigger led to a quick restructuring of both economies and public relations. True, most often these reasons were not peaceful: the idea of universal equality required 20 million losses in the First World War, and the idea of the highest value of human life was established as a result of the Second World War with its 50 million dead. The corona virus pandemic is nothing but the Third World War in the only form in which it is possible today. In terms of the scale of losses and destruction, it is impossible, of course, to compare it with the two previous ones, but in terms of the effect produced on politics and the economy, society and consciousness, they are quite comparable. And just like that, the latest technologies that have developed exponentially over the past two decades have only been waiting for a trigger to trigger a new grand transformation of society. The technological platform, infrastructure, and com- 
munications system that have been created over the past three decades have become the battlefield in this war, and the latest technology itself has become the main weapon. They will allow us to win: after all, in this war, unlike the previous ones, all of humanity appears on one side. The delivery service, which yesterday occupied a couple of percent of the retail market, and even then only in megacities of developed countries, is experiencing explosive growth, conquering small cities and is unlikely to slow growth even after the lifting of restrictions. The market of distance education, the benefits of which the experts argued lazily, is beginning to dominate the traditional university. In a matter of weeks, new online services appeared which only the most daring futurologists had previously spoken about. Behind the external transformation, the second, even more powerful wave is the internal. The transition of tens of millions of people to remote work within one week leads to amazing discoveries. The employee, it turns out, spends working time at home more efficiently. There he does not chase endless tea in the corporate kitchen, does not smoke with colleagues at the entrance, and does not talk with a partner about the weather in the meeting room. The traffic of watching TV shows during working hours did not increase significantly, but the traffic of corporate instant messengers and online education sites is off-scale. The employer is surprised to realize that remote work can be one-third more efficient than office work. Moreover, renting a glamorous office in the class "A" business centre has been unnecessary in these days. Co-working, which yesterday seemed like an innovation, today looks like an outdated transitional link to the remote type of employment and is unlikely to return to us. As a result, the direct connection between the consumer, supplier, employee and the place of direct decision-making on a specific request was reduced from days or weeks to literally milliseconds (Elinson, 2020).

Traditional work place is becoming a thing of the past and changes in our life, including economic factors which are making organizations to re-think the way they do business and develop different approaches to work (Victor, 2009). Beyond the actual redesigning of jobs and the use of employee involvement, many organizations today are experimenting with a variety of flexible working arrangements (FWA). These arrangements generally aim to strengthen employee motivation and performance by giving workers more flexibility about where, when and how work gets done (Griffin \& Moorhead, 2013).

\section{Flexible Working (FW) as a Developing Modern Practice}

The traditional workplace has seen significant changes over the past few decades and increasing number of companies around the world are offering a range of FW options. Justina Victor (2009) interprets it by several reasons:

- Technological advances.

- Increase in global competition/economy.

- Dual-income households.

- Increased number of employees with caring responsibilities. 
- Varying needs of different generations in the workplace.

- Single parent families.

- Sustainability.

In addition, it has been observed that "demographic and social trends" (Prystay, 2010) have major impact on workplace. For instance, in Asia's work culture office hours are typical measurement of an employee's performance which has been the biggest obstacle to FW practices. Today FWAs which were uncommon in Asia in the past are gaining popularity in the regions like Singapore where FWAs are gaining popularity as birth rates fall and populations get older. Singapore definitely has scarce human capital, so talent retention is a major factor why companies are starting to implement flexible work arrangements (ibid).

The types of positive organizational outcomes planned by employers are quite diverse including high job performance, cost-effectiveness, quality problem solving, successful change, lover turnover, absenteeism and complaint rate and high cost-effectiveness (Rees \& French, 2010 cited in Iles et al., 1996), whereas employee's flexibility requirements coincide efficiency and attempting to juggle the demands of home and work lives (CIPD, 2005).

From theoretical point the term of flexibility does not have direct definition. It is umbrella-term including a broad range of practices, work arrangements and work force organization systems (Canibano, 2011 cited in Kelliher \& Anderson, 2008: p. 420) that frequently seen as a key management program goal, along with strategic intention, quality, and employee commitment, in order to ensure and adaptable organization structure (Rees \& French, 2010). More popular flexible work arrangements include flexible working schedules, part-time job, job sharing, telecommuting and compressed work week (Rothwell et al., 2012).

\subsection{Flexible Working Hours (FWH)}

FWHs give employees control over the hours they work each day (Griffin \& Moorhead, 2013). It is scheduling policy that employees may choose starting and ending times within guidelines specified by the organization (Noe et al., 2004). "Employees are still required to carry out 40-hour workweek on their workplace, but they have control over the hours when they perform the work" (Gomez-Mejia et al., 2012). FWHs divide work schedules into core time, say, between 10:00 am and 3:00 pm, when all employees are expected to be at work and where meetings and team activities take place in this core time and flexible time (flextime), when employees can choose to organize work routines around personal activities including to make time for doctor's appointments, children's activities, hobbies or volunteer work (Noe et al., 2004). According to recent surveys, approximately 27 million full-time workers in the United States have some degree of flexibility in when they begin and their work days. Organizations that use flextime include Sun Microsystems, IBM, Hewlett-Packard, Xerox, Best Buy, Pricewaterhouse Coopers and some offices in the U.S. government (Griffin \& Moorhead, 2013; Pricewaterhouse Coopers, 2009). 


\subsection{Part-Time Working (PTW)}

Part time is when employees work less than the normal basic full-time hours (ACAS, 2013). PTW program is comprised of different options. First, it is consistent, voluntary employment with fewer hours of work per day, week, month, or year than normal full-time employment. Regular part-time employees have stable work obligations, prorated pay and benefits, and expectations to become full-time employees. Second, part time engagement is contingent employment consisting of hourly paid work without job security, regular work hours, or benefits (Peters, et al., 1998). It may be chosen by employer who have his or her prime interests, or it may be chosen involuntarily by worker because of lack of other employment opportunities available (ibid). "Contingent workers hired to deal with temporary increases in an organization's workload or to do with work that is not part of its core set of capabilities" (Gomez-Mejia et al., 2012). Employment of contingent workers is connected with the employer's convenience and efficiency needs. When the business begins to undergo a downturn, contingent workers who provide a buffer zone for core workers are the first employees to be discharged (ibid:76). For instance, some large Japanese corporations protect their core workers by a large contingent of employees that can be downsized when business conditions change (ibid: 76).

PTW is mainly associated with the service sector and with female employment, but its practical applications may vary according to country-specific patterns of industrial organization, labor market regulation, and gender relations (Peters, Greer, \& Youngblood, 1998 cited in Rubery and Fegan 1993). Every one out of four in British labor force is part-time workers and $80 \%$ of them are women (ACAS, 2013).

\subsection{Job Sharing (JS)}

JS is a special type of part-time employment where one full-time job is divided into between two part-time employees (Gomez-Mejia et al., 2012; Griffin \& Moorhead, 2013). Griffin and Moorhead (2013) indicate that companies offer JS as a way to entice more workers to the organization. If a certain job is difficult to fill, JS might make it more attractive to people. Thus full-time pay and benefits are divided to each sharer according to time they worked. JS does not fit for each organization and not all workers do want step into it, it usually occurs in organizations that on a case-by-case basis and happens among a variety of occupations from production workers to professionals' (Peters, et al., 1998). JS has produced enough success stories in CNN, Wegmans, Google, SAS, and DreamWorks Animations (Griffin \& Moorhead, 2013).

\subsection{Telecommuting/Mobile Workplace}

Modern technologies have brought significant changes to our life over the past few decades. Laptops, smartphones, the Internet and other technology have created opportunity to employees to contact with their organization and do as much work at home as they could in office. Gomez-Mejia et al. (2012) note that 
the widespread use of laptops, cell phones and the availability of Wi-Fi hot spots in many public places have given rise to a new work environment, one where employees can work from many different locations. "Employees no longer have to be tethered to the office in order to work. Technology has freed employees to work in many different locations, including team spaces, remote work centers, a home office, or the neighborhood coffee shop" (ibid). Pruchno (2000) presents an additional measurement to the notion of telecommuting, namely it is schedule in which employees conduct their work outside of their office may be from their home of employee or satellite office in parts of their core working hours, Overall, it is option that one may work away from office known as telework or telecommuting which brings the distant worker to the workplace electronically' (Rowley \& Jackson, 2010; Peters, Greer, \& Youngblood, 1998).

Telecommuting enables employees to work from home when there is bad weather or widespread health issues. In addition, it allows people with busy schedules to participate in meetings even they are far from the conference location. Modern IT technologies and other sophisticated equipment make it available for employees at remote locations to teleconference with one another as if they are all seated in the same room. Employees who are using flexible workplace arrangement have lower rate of absenteeism than employees who must commute to work. Generally, a telework arrangement is difficult to set up in manufacturing workers. It is easier to implement for people in managerial, professional, or sales jobs, especially to those who involve working and communication on a computer (Rowley \& Jackson, 2010; Gomez-Mejia et al., 2012). Companies that are successfully implementing e-commuting arrangements are IBM, Motorola, AT \& T, Best Buy and FedEx (Gomez-Mejia et al., 2012; Griffin \& Moorhead, 2013).

\subsection{Compressed Work Week (CWW)}

Traditional work schedules make difficulties for workers to cope with their routine personal businesses including going to the bank, dentist's check-up, parent-teacher conference, getting an automobile serviced. One alternative in order to encounter these problems, some organizations use CWW schedules (Griffin \& Moorhead, 2013). It is the schedule that full-time employees perform weekly hours of their job less than traditional five days. CWW schedule contains the same work hours as traditional one, but the number of hours worked in a day increases. A variety of CWW schedules also exist, but the most common alternative is the four day, employee may complete 40 hours of work in four 10-hour days (Peters, et al., 1998). Gomez-Mejia et al. (2012) indicates that compressed workweeks decrease disruptions to businesses that provide 24/7 services such as hospital and police forces. It also causes lower rate of absenteeism and tardiness at with work sites in remote areas that require long commutes to work such as off-shore oil drilling platforms (ibid). Firms that use forms of compressed workweeks include Recreational Equipment, ASAA, Edward Jones, and Mercedes-Benz USA (Griffin \& Moorhead, 2013). 


\section{Perceived Outcomes of FW}

Being able to work flexibly may, at first glance, appear to be the answer to the work/life balance conundrum with no apparent downsides. However, before applying a flexible working, it is important to consider all aspects of what's involved. This means taking off the rose-tinted spectacles and thinking about what some of the disadvantages may be and how they may affect you.

\subsection{Benefits of FW}

- High retention of staff and organizational knowledge;

- Positive impact on productivity, morale and quality of work;

- Less absenteeism, employee turnover and tardiness;

- Better work-life balance, high life satisfaction;

- Contended and committed employees;

- Retention of more qualified workforce;

- May reduce commuting time and costs;

- Capacity to meet peak demands outside normal hours (Neo, 2013; Pruchno, 2000; Massachusetts Institute of Technology, 2004).

\subsection{Possible Disadvantages}

- A lack of the culture of presenteeism in organizations;

- Stress due to increased work hours;

- Workloads;

- Alienation and disassociation with the organization;

- Impersonal virtual teams reduce relationship;

- Level of trust including the psychological contract between employer and employee (Neo, 2013; McNamara et al., 2012).

\section{Managing FW}

Embedding a FW culture within an organization is not straightforward. In order to ensure that people are managed effectively and aims are achieved, policies need to be reviewed in the context of all employees, whatever their arrangements. Therefore, examining strategies that are required in response, barriers and challenges is useful (Kelliher \& Anderson, 2008).

\subsection{Supervisor's Role}

Role of supervisors is vital to the success of an organization's FWAs. They must be ready to manage the company under the settings of arrangement. According to survey conducted by University of Chicago, FWAs will be successful if supervisors can

- measure the advantages derived by implementing FWAs;

- concentrate on suitability of employee who is going to choose flexible work options; 
- support the idea through personal modeling of balanced work practices; link clear duties and expectations;

- cope with problems may develop;

- create result oriented performance atmosphere;

- apply everyday management skills that can unify mission of company and expectations of employees;

- regularly inform about worker's feedback after analyzing performance;

- change a plan if FWAs do not correspond to the needs of organization;

- consider workloads for hourly-paid;

- choose the person in the unit who can be example to others so that accruals will try to correspond to the work schedule (Leslie et al., 2012).

\subsection{Key Issues for Managers of Flexible Staff}

Managers may encounter with some issues that arise during implementation of FWAs. Firstly, they need to achieve getting the job done, carry out detailed forecasting of work volume, and how their work will be done, for example, with responsibility shared across a team rather than relying on the availability of a specific staff member. Secondly, they need to address intensification of work, as it is frequently complained by part-time employees and telecommuters who move from full time to FWAs that their workload is not reduced to match their new hours. Thirdly, managers need to identify and resolve any issues among colleges and teams who are users and nonusers of FWAs, because colleges may feel jealous, especially if some employees have access to FW options while others not (Australian Institute of Management, 2012).

\subsection{FWA Proposals Need to Consider}

In order to implement FWAs successfully each aspect of these options must be planned carefully. Approaching each FWA can make managing FW users a little easier. There are a number of flexible schedule proposals need to think through including maintaining office and department coverage (e.g., through establishing core hours), establishing and preserving effective ways of communication with user of flextime (Massachusetts Institute of Technology, 2004).

Managers of PT workers should be ready for the questions that in reduced hours what work need to be done, how the rest of colleges cope with employee's work, evaluate standards to measure performance of employee and impact of PTW on employee's career advancement (ibid).

Implication of JS arrangements also will bring some questions including dividing work responsibilities between sharers, each partner's work hours, sharer's communication with each other, their manager, co-workers, clients, evaluating each partner as a team and individually, tackling the problem when a job-share partner leaves and bearing on mind that what to do if the trial job-share does not work (ibid).

Manager of telecommuters need select telecommuters with care and consider 
the work habits of the employee and the type of work involved because people who are not very self-motivated may not be able to manage their time well at home. In addition, developing a well-planned telecommuter's plan that include performance expectations with measurable results. Managers must develop new skills and learn to transition from managing with a focus on employees' behaviors and time to one with an emphasis on managing by results. Supervision and evaluation of arrangement, supporting with technical equipment, telecommuter's communication with co-workers and managers which need to hold uninterrupted and their time spend in the office are another crucial questions that managers should address (Massachusetts Institute of Technology, 2004; Gomez-Mejia et al., 2012 cited in HR Focus, 2008, Fisher A. 2005).

\section{Conclusion}

Today, the essence of traditional working hours in the office has shifted to where, when and how work gets done. Global competition among companies, demand for skilled labor force, economic crisis and other factors are contributors to these changes. Popular alternative arrangements including compressed workweeks, flexible work schedules, part-time working, job sharing and telecommuting are being used to enhance job performance.

Implementation of FWAs around the world has proved to have more benefits than drawbacks. Organizations take an advantage of having increased job satisfaction, loyalty, social responsibility, productivity, and reduced stress levels, absenteeism. As more organizations and employees benefit from it, these options will continue to grow in popularity.

However, some complexities connected with flexible work arrangements may arise while managing users of FWAs. It depends on supervisors/managers to apply special approaches to the management of people and address the challenges which may bring inconveniencies to both employers and employees.

\section{Conflicts of Interest}

The author declares no conflicts of interest regarding the publication of this paper.

\section{References}

ACAS (2013). Flexible Working and Work-Life Balance. ACAS Booklet.

Australian Institute of Management (2012). AIM Managing in a Flexible Work Environment. Green Paper.

Canibano, A. (2011). Exploring the Negative Outcomes of Flexible Work Arrangements. The Case of a Consultancy Firm in Spain. HRM in Knowledge Economy: BAM HRM Special Interest Group Conference, London, 5-6 May 2011, 32 p.

CIPD (2005) Flexible Working: Impact and Implementation. London: Chartered Institute of Personnel and Development.

Elinson, А. (2020). Третья мировая и победа справедливости: каким будет мир после вируса. Forbes. 
https://www.forbes.ru/obshchestvo/396211-tretya-mirovaya-i-pobeda-spravedlivosti-k akim-budet-mir-posle-virusa

Gomez-Mejia, L. R., Balkin, D. B., \& Cardy, R. L. (2012). Managing Human Resources (7th ed.). Upper Saddle River, NJ: Pearson Education, Inc.

Griffin, R. W., \& Moorhead, G. (2013). Organizational Behavior: Managing People and Organizations (11th ed.). Mason, $\mathrm{OH}$ : Cengage Learning.

Iles, P., Foster, A., \& Tinline, G. (1996). The Changing Relationship between Work Commitment, Personal Flexibility: An Evaluation of a Field Experiment in Executive Development. Journal of Managerial Psychology, 11, 18-34. https://doi.org/10.1108/02683949610150033

Kelliher, C., \& Anderson, D. (2008). Flexible Working and Performance: Summary of Research. London: Cranfield University School of Management \& Working Families.

Leslie, L. M., Manchester, C. F., Park, T.-Y., \& Mehng, S. A. (2012). Flexible Work Practices: A Source of Career Premiums or Penalties? Academy of Management Journal, 55, 7-28. https://doi.org/10.5465/amj.2010.0651

Massachusetts Institute of Technology Center for Work (2004). Family \& Personal Life A Guide to Job Flexibility at MIT: Tools for Employees and Supervisors Considering Flexible Work Arrangements. Massachusetts.

McNamara, T. K., Pitt-Casouphes, M., Brown, M., \& Matz-Costa, C. (2012). Access to and Utilization of Flexible Work Options. Industrial Relations, 51, 936-965.

https://doi.org/10.1111/j.1468-232X.2012.00703.x

Neo, J. (2013). Motivation and Empowerment//Managing and Leading People. Suderland Business School.

Noe, R. A., Hollenbeck, J. R., Gerhart, B., \& Wright, P. M. (2004). Fundamentals of Human Resource Management. New York: McGraw-Hill Companies, Inc.

Peters, L. H., Greer, C. R., \& Youngblood, S. A. (1998). The Blackwell Encyclopedic Dictionary of Human Resource Management. Malden, MA: Blackwell Publishing Ltd.

PricewaterhouseCoopers LLP. (2009). Meeting Tomorrow's Workforce Needs: Flexible Workforce Arrangements.

Pruchno, R., Litchfield, L. C., \& Fried, M. (2000). Measuring the Impact of Workplace Flexibility: Findings from the National Work/Life Measurement Project. Boston, MA: Boston College Center for Work \& Family.

Prystay, C. (2010). Once Unheard of in Asia, Flexible Work Practices Gain Traction. http://www.cnbc.com/id/39946535

Rees, G., \& French, R. (2010). Leading, Managing and Developing People (3rd ed.). London: Chartered Institute of Personnel and Development.

Rothwell, W. J., Lindholm, J., Yarrish, K. K., \& Zaballero, A. G. (2012). The Encyclopedia of Human Resource Management. San Francisco, CA: John Wiley \& Sons, Inc.

Rowley, C., \& Jackson, K. (2010). Human Resource Management. New York: Taylor \& Francis Group e-Library. https://doi.org/10.4324/9780203841815

Victor, J. (2009). Workplace Flexibility in the 21st Century: Meeting the Needs of the Changing Workforce. Alexandria, VA: Society for Human Resource Management (SHRM). 